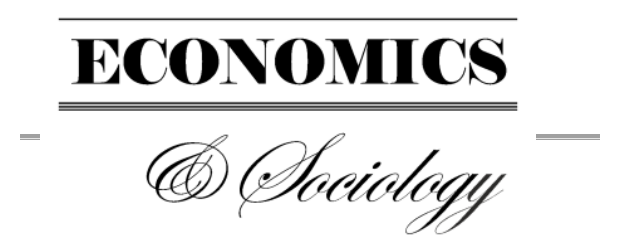

Babiarz, P., Grabiński, T., Migała-Warchoł, A., \& Szczygieł, E. (2018). The application of customized human development index to the analysis of socioeconomic development of the European Union member states. Economics and Sociology, 11(4), 332-342. doi:10.14254/2071-789X.2018/11-4/22
Patryk Babiarz, University of Georgia, Athens, GA, USA E-mail:pbabiar:@uga.edu

Tadeusz Grabiński, Cracow University of Economics, Kraków, Poland,

E-mail:tg@uek.krakow.pl

\author{
Aldona Migała-Warchoł, \\ Rzeszón University of Technology, \\ Rzeszón, Poland, \\ E-mail:amigala@prz.edu.pl \\ Elżbieta Szczygiex, \\ Rzeszón Regional Development \\ Agency, \\ Rzeszón, Poland, \\ E-mail:eszcrygiel@rarr.rzeszow.pl \\ Received: May, 2018 \\ 1st Revision: September, 2018 \\ Accepted: December, 2018
}

DOI: $10.14254 / 2071-$

789X.2018/11-4/22

JEL Classification: C15, C240, D31, I31, O15

\section{THE APPLICATION OF CUSTOMIZED HUMAN DEVELOPMENT INDEX TO THE ANALYSIS OF SOCIO- ECONOMIC DEVELOPMENT OF THE EUROPEAN UNION MEMBER STATES}

\begin{abstract}
The purpose of this publication is to examine the determinants of socio-economic development of the European Union member states and to rank order the analysed countries by the value of synthetic index of wellbeing. The study implements a framework modelled after the Human Development Index to obtain a customized synthetic measure of the standard of living. The proposed index accounts for a rich set of variables related to the performance of economy, science and technology, health, education and living conditions. The data for empirical analysis are drawn upon the Eurostat databases and cover years 2006 through 2016. The analysis presented in this study is intended to advance the efforts to adjust the traditional measures of development so that they better reflect the contemporary challenges faced by diverse societies.
\end{abstract}

Keywords: socioeconomic development, HDI index, synthetic index, modified development index.

\title{
Introduction
}

Numerous international organizations and researchers recognize the need to find new measures of the quality of life as those that have traditionally been used increasingly fail to capture the complex social and economic dimensions of life in a contemporary society. The purpose of this paper is twofold. First, it expands a popular measure of living standard, the 
Human Development Index, into a more comprehensive framework that accounts for a richer set of indicators of socio-economic development. Second, it presents a comparative analysis of the European Union (EU) member states. The paper complements and extends a series of articles that apply this modified synthetic measure of socio-economic development to the analysis of EU countries (Migała-Warchoł, 2017; Migała-Warchoł, 2018; Migała-Warchoł, Szczygieł, 2018). This novel analytic framework accounts for several variables that determine socio-economic development and, therefore, are presumed to affect the standard of living. These factors are grouped into categories such as economy and finance, science and technology, health, education and living conditions.

The empirical analysis utilizes data from the Eurostat database for the years 20062016. The paper lays out the procedure employed to calculate the synthetic measure of living standard. Constructing such an index allows for a precise assessment of the amount of variation in the socio-economic development of EU countries that can be attributed to individual determinants. The linear regression method is also used to estimate the marginal effects of each of the determinants on the average level of socio-economic development. Finally, the method of delimiting objects and the cluster analysis with Ward's minimum variance criterion are employed to group and rank order the EU member states by the value of synthetic index of the socio-economic development.

\section{Literature review}

Economic growth is one of the key determinants of socio-economic development and well-being. While the effects of economic growth amount to the multiplication of production factors, the effects of development are broader and may include non-economic consequences. The growth is quantitative in nature while the development may also be assessed qualitatively and could consider diverse dimensions of social interactions. An increasing number of researchers acknowledge that social welfare needs to be measured in broader terms than just the increase of gross domestic product (Kubiczek, 2014; Islam, \& Clarke, 2002). As stated by Woźniak (2017, p. 10-11), "comprehensive human development (...) is associated with the implementation of not only economic aspirations expressed in greater use in gross domestic product (...), but also with the implementation of the spiritual aspiration and the intellectual dimension of the individual's existence in harmony with the environment in which he or she lives".

The quantitative measure of economic growth is calculated as proportional change over time in the value of gross domestic product (GDP). This approach to national accounting was proposed in response to the need for tools that would help evaluate the effectiveness of policies implemented by national governments to counteract the adverse effects of the Great Depression of the 1930s (Petelewicz, \& Drabowicz, 2016). Even then, however, it seemed clear that economic development was a deficient measure of total societal welfare, as evidenced by Pigou (1932, p. 12) who stated: "economic welfare will not serve for a barometer or index of total welfare". The problem with measures that are based on economies' productive capacities is that they do not account for those aspects of the quality of life that are qualitative in nature (e.g., access to healthcare or education). This seems particularly problematic given that the non-material aspects of societal progress have grown in significance with the transition of industrial society into the post-industrial phase and economists increasingly need to "focuse attention on what human beings can do, instead of on what they have" (Stanton, 2007, p. 9).

The European Commission has clearly indicated the need to "move away from GDP" towards synthetic indicators that would comprehensively describe the functioning and well- 
being of individuals and communities (Stiglitz, Sen, \& Fitoussi, 2009). One example of such a synthetic indicator of well-being is the Quality of Life Index that measures the quality of life in terms of costs of living, education, health, democracy, safety and the environment (Kasprzyk, 2013). Another prominent example is the Human Development Index (HDI) that measures the level of social development and is often applied to rank order countries. The HDI was created by Mahbub ul Haq in 1990 with the help and advice of Amartya Sen (ul Haq, 2003; Anand, Sen, 1994). Sen was also among the first to draft the assumptions of what the comprehensive measurement of socio-economic development should account for, although "at first he did not see the point of a crude composite index like the HDI, especially against the backdrop of the wealth of information that the United Nations Development Program (UNDP) was planning to include in the report" (Santon, 2007, p. 14). A widely known reply of ul Haq ("We need a measure of the same level of vulgarity as GNP - just one number - but a measure that is not as blind to social aspects of human lives as GNP is."; Sen, 1999 , p. 23) convinced the UNDP staff to propose the complex measure of human development.

The construction of the index required an operationalization of the broad concept of human development. It was believed that a combination of separate indices within three areas, health, education and income, into a single composite index would adequately summarize the well-being (Aguña, \& Kovacevic, 2010; Kovacevic, 2010). Throughout the 28 years since its inception, the indicator has been systematically improved and the modification ranged from the methods of calculating the minimum and maximum values of component indicators to the changes of indices included in the final measure. In result, the current version of HDI is composed of indices which correspond to three basic dimensions of human development: (1) a long and healthy life (measured by life expectancy at birth), (2) knowledge (measured by the mean/expected years of schooling), and (3) a materal standard of living (indicated by an income index designed to proxy for purchasing power). The synthetic measure of HDI is obtained by calculating the geometric mean of the standardized component of the index indictors. The HDI is a popular measure used to rank order countries on a scale from 0 (the lowest level of human development) to 1 (the highest level).

Despite the numerous modifications incorporated into the design of the HDI, literature frequently reports on proposals to further modify the index. The proposed modifications range from different ideas for the index components to the methods of calculation (see: Noorbakhsh, 1998; Neumayer, 2001; Despotis, 2005; Grimm, Harttgen, et. al. 2010; Kovacevic, 2010; AlHilani, 2012; Mishra, \& Nathan, 2018). Some of the most important and interesting of the proposed modifications concern the identification of areas of human development. For example, Ranis, et al. (2006) identified 11 categories of human development: mental wellbeing, empowerment, political freedom, social relations, community well-being, inequalities, work conditions, leisure conditions, political security, economic security, environmental conditions. Silva and A. Ferreira-Lopes (2014) enriched the three original dimensions of HDI with two new ones, governance and environment. Migała-Warchoł (2010) advanced the analysis of human development by examining a large number of new potential categories, and eventually adding components related to finance and economy, science and technology and living conditions (Migała-Warchoł, 2017; Migała-Warchoł, 2018; Migała-Warchoł, Szczygiel, 2018). Along with the increasing dimensionality of the index, researchers have also tested ideas for new variables within the categories. For example, Ranis, et al. (2006) examined 39 separate variables and retained 31 to be included in his version of the index. Similarly, A. Migała-Warchoł conducted her initial analyses using 27 independent indicators.

All the modifications described above are part of the effort to develop new synthetic indexes that would be better tailored to the unique and evolving societal challenges, and 
capable of gauging the concept of quality of life with greater precision and adequacy. For example, to account for the increasing importance of environmental factors, Maccari (2014; Busato, Maccari, 2016) proposed the Environmental Human Development Index which enriched the human development framework with the concept of environmental sustainability. Similarly, in response to the challenges faced by the aging societies, Jha, et al. (2017) proposed the Health Adjusted Human Development Index.

Many international organizations and scientists emphasize the necessity to further improve the current measures of well-being with solution that would allow for better identification and assessment of policy responses to the unique challenges faced by individual countries. The HDI plays the key role in this process for two reasons. First, it popularizes the idea of a single measure of human development as a means to better understand the concept of well-being. Second, it is a viable alternative to the deficient yet still very popular measure of GPD per capita (Stanton, 2007). It is difficult to disagree with the statement by Kubiczek (2014, p. 40): “... so far no common methodology for constructing development measures has been developed, despite the fact that there are more and more variants of measures, and they are becoming more and more comprehensive". This paper intends to make a contribution to the process of finding and developing a new index that would advance the process of measuring the quality of life.

\section{Methodology}

The construction of the synthetic measure of development requires that the diagnostic variables are grouped into distinct sets of stimulants and inhibitors of development. Variables included in the set of stimulants are marked with the plus sign (+), while the minus sign (-) is used to denote inhibitors. The following formula is used to transform inhibitors into stimulants:

$$
x_{i j t}^{\{S\}}=\max _{i, t} x_{i j t}^{\{D\}}-x_{i j t}^{\{D\}}
$$

where:

$x_{i j t}$ is the value of the $\mathrm{j}$-th variable for the $\mathrm{i}$-th country,

$\mathrm{S}$ indicates a stimulant, $\mathrm{D}$ denotes an inhibitor.

Next, the variables are normalized according to the following formula:

$$
u_{i j t}=\frac{x_{i j t}}{\max _{i, t}\left\{x_{i j t}\right\}}(i=1, \ldots, n ; j=1, \ldots, m ; t=1,2, \ldots 11)
$$

where:

$u_{i j}$ is the normalized value of the $\mathrm{j}$-th variable for the $\mathrm{i}$-th country,

$n$ is the number of countries,

$m$ is the number of variables,

$t$ indicates the time period.

The synthetic measure of socio-economic development is calculated by the following formula:

$$
u_{i t}=\frac{1}{r} \sum_{q=1}^{r} u_{i q t},(i=1, \ldots, n ; q=1, \ldots, r ; t=1,2, \ldots 11)
$$


where:

$u_{i q}$ is the value of synthetic variable for the i-th country calculated on the basis of the variables belonging to the q-th determinant,

$r$ is the number of determinants,

$t$ indicates the time period.

In contrast, the measures of socio-economic development specific to each of the determinants is calculated using the following formula:

$$
u_{i q t}=\frac{1}{m} \sum_{j=1}^{m} u_{i j t},(i=1, \ldots, n ; j=1, \ldots, m ; t=1,2, \ldots 11)
$$

A detailed list of determinants and indicators of socio-economic development is provided below. The selection of these variables is based on prior literature and the availability in Eurostat data for the years 2006-2016. Given the intended comprehensive nature of the constructed measure of living standard, the proposed determinants and indicators of socio-economic development encompass the domains of economy and finance, science and technology, health, education, and living conditions.

The determinants are calculate with the use of the following indicators:

I. Economy and Finance

1. Unemployment rate (-)

2. GDP per capita $(+)$

3. Indicator of real expenditure per 1 inhabitant $(+)$

4. Number of poor people per 1000 inhabitants (-)

II. Science and Technology

1. Gross domestic expenditure on research and development (\% of total expenses) $(+)$

2. Human resources in science and technology (\% of the active population) $(+)$

3. Number of patent applications submitted to the European Patent Office per million inhabitants (+)

4. Number of researchers per 1000 inhabitants $(+)$

III. Health

1. Self-reported long-standing limitations in usual activities due to health problem (-)

2. Self-reported unmet needs for medical care due to being unaffordable (-)

3. Life expectancy $(+)$

4. Number of hospital beds per 100000 inhabitants (+)

IV. Education

1. Participation rate in education and training (persons aged 25 to 64 years old) $(+)$

2. Percentage of people with at most lower secondary education and with no further education at the age of 18-24 years old (-)

3. Percentage of people aged 15 to 64 with higher education or those still receiving education $(+)$

4. Percentage of people aged 15 to 64 with secondary education (+)

V. Living Conditions

1. Percentage of people who are unable to meet unexpected financial expenses (-) 
2. Percentage of people who are unable to make 'ends meet' (-)

3. Rate of people at risk of poverty (-)

4. Share of people living in under-occupied dwellings $(+)$

\section{Results}

The analysis proceeds by estimating the linear regression models that are used to quantify and evaluate the distinct effects of determinants on development. Next, the synthetic measure of socio-economic development is used to group and rank order the European Union member states using two methods: (1) the method of delimiting objects and (2) the cluster analysis with Ward's minimum variance criterion.

\subsection{Linear regression analysis}

Figures 1-5 show the results from linear regression models in which the dependent variable, the modified synthetic measure of socio-economic development of EU countries (calculated on the basis on the indicators presented in the previous section), is regressed on the determinants of socio-economic development: economy and finance, science and technology, health, education and living conditions.

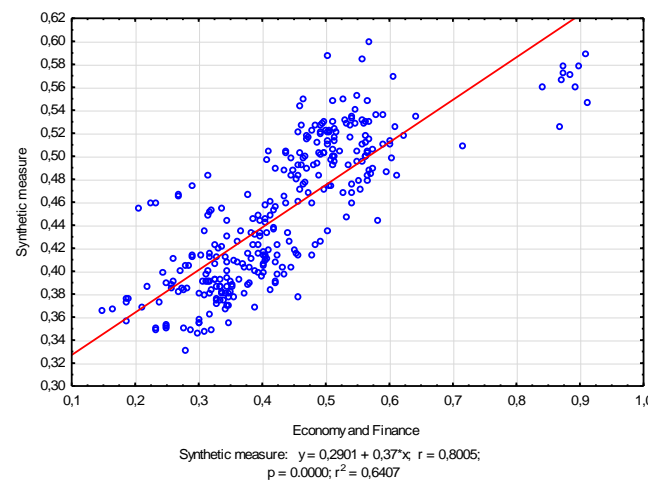

Figure 1. Regression of the synthetic measure of development on the index variable for economy and finance

Source: own compilation

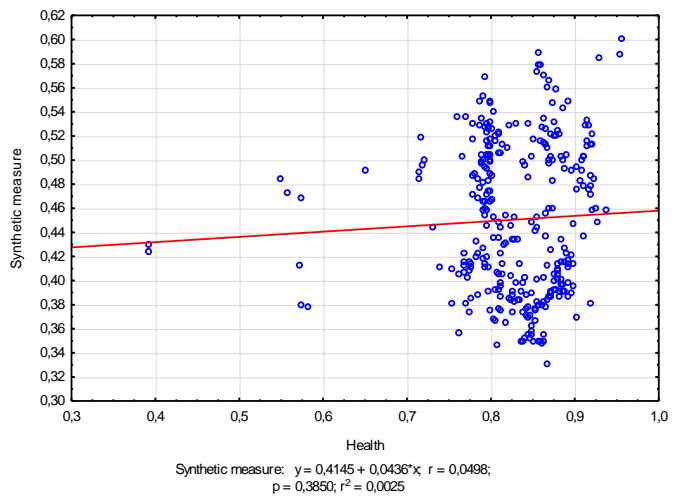

Figure 3. Regression of the synthetic measure of development on the index variable for health

Source: own compilation

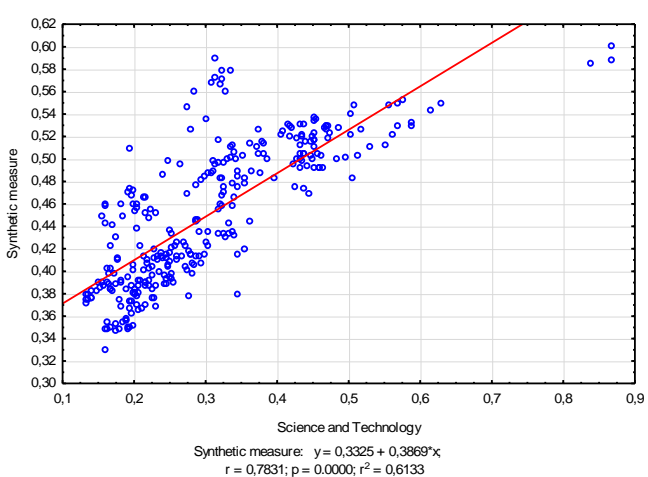

Figure 2. Regression of the synthetic measure of development on the index variable for science and technology

Source: own compilation

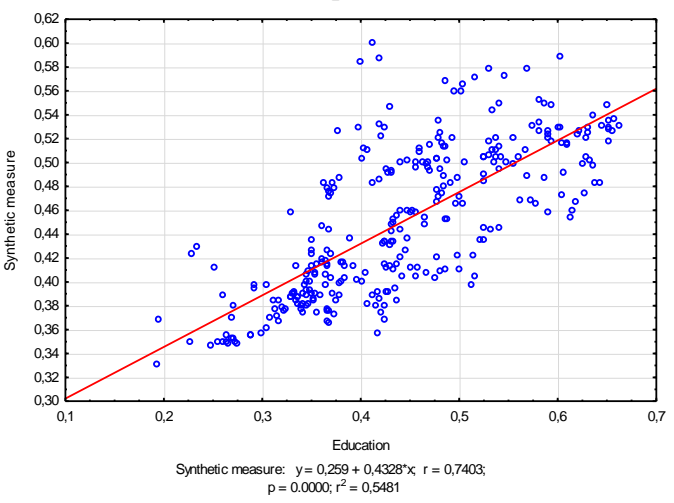

Figure 4. Regression of the synthetic measure of development on the index variable for education Source: own compilation 


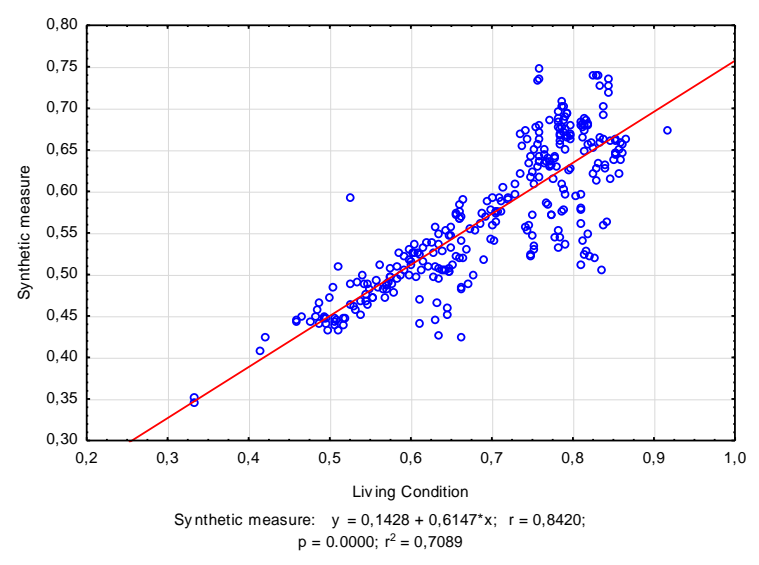

Figure 5. Regression of the synthetic measure of development on the index variable for living condition Source: own compilation

The models of regression functions (presented in Figures 1-5) provide estimates of marginal effects for each of the determinants of socio-economic development as well as the model fit statistics. The marginal effects reveal the expected magnitudes of change in the synthetic measure associated with one unit increases in the value of each determinant. The model fit statistics allow to assess which of the determinants has the greatest individual ability to predict the socio-economic development of EU countries. It can be observed that economy and finance $(r=0.8)$, science and technology $(r=0.78)$ and living conditions $(r=0.84)$ have the greatest impact on socio-economic development. The estimated marginal effects reveal that a one unit increase in measurement of the determinant is expected to increase in the synthetic measure by 0.37 if the determinant is economy and finance, 0.39 if the determinant is science and technology, 0.04 for health, 0.43 for education, and 0.61 for living conditions.

\subsection{Method of delimiting objects}

In the next step, the method of delimiting objects is applied to rank order the EU countries. The full description of this method can be found in (Grabiński, 2017). The EU member states are arranged according to the values of the modified synthetic measure of socio-economic development and a symmetrical matrix is created. The symbols $\mathrm{X}$ denote here $30 \%$ of measures indicating the highest level of the countries similarity. Groups of countries are designated by squares containing mainly symbols $\mathrm{X}$ and at the same time surrounded by outside empty cells in which there are parameters indicating a lower level of similarity of the countries.

It can be observed that four countries, the United Kingdom, Denmark, Sweden and Finland, lead the classification with the highest values of the modified synthetic measure of socio-economic development. This leading group is followed by a group of three countries: Estonia, Netherlands and Lithuania. The largest cluster in the middle of the ranking list comprises ten countries from Luxembourg to the Czech Republic. The next group consists of four countries: France, Poland, Greece and Slovakia, followed by the group of Hungary, Latvia, Slovenia and Bulgaria. Finally, the last group includes the three weakest countries: Italy, Romania and Portugal. Parameter Q means incompatibility error which was counted as summed up 14 empty fields that fit in the selected squares (colored orange) and those that are outside them ( 8 colored yellow) compared to all fields in the whole square (784). The total 
number of cells with similarity measures incompatible with the designated delimitation is small and constitutes $2.8 \%$ of the total number of measures.

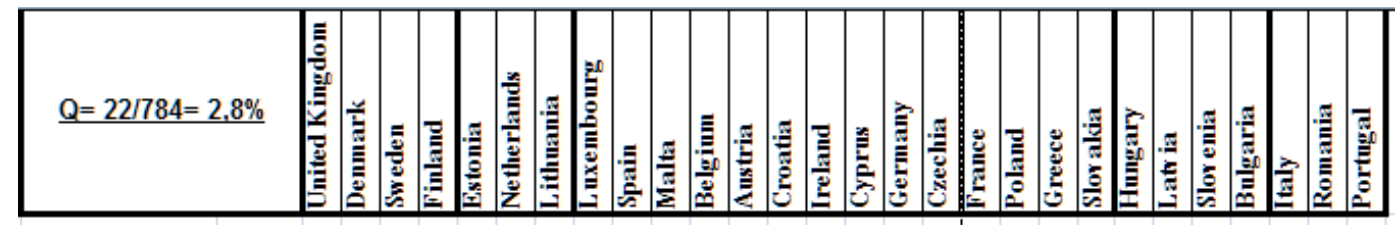

\begin{tabular}{|c|c|c|c|c|c|c|c|}
\hline United Kingdom & 0,79 & \begin{tabular}{l|l}
$X$ & \\
\end{tabular} & & & & & \\
\hline Denmark & 0,69 & $\mathrm{X}$ & & & & & \\
\hline Sweden & 0,65 & $\mathrm{x}$ & & & & & \\
\hline Finland & 0,62 & $\mathrm{X}$ & & & & & \\
\hline Estonia & 0,60 & & 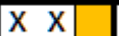 & & & & \\
\hline Netherlands & 0,59 & & $x \times x$ & & & & \\
\hline Lithuania & 0,57 & & $7 \times x$ & & & & \\
\hline Luxembourg & 0,54 & & & $\begin{array}{lllll} & X & X & X & \\
\end{array}$ & & & \\
\hline Spain & 0,52 & & & 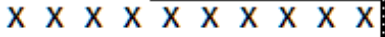 & & & \\
\hline Malta & 0,52 & & & 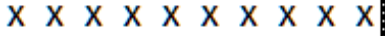 & & & \\
\hline Belgium & 0,52 & & & 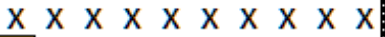 & & & \\
\hline Austria & 0,52 & & & $\begin{array}{lllllllllll} & \mathrm{X} & \mathrm{X} & \mathrm{X} & \mathrm{X} & \mathrm{X} & \mathrm{x} & \mathrm{X} & \mathrm{X} & \mathrm{X}\end{array}$ & & & \\
\hline Croatia & 0,52 & & & 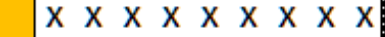 & & & \\
\hline Ireland & 0,52 & & & 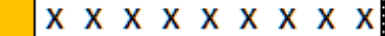 & & & \\
\hline Cyprus & 0,51 & & & 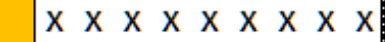 & $x$ & & \\
\hline Germany & 0,51 & & & 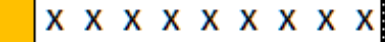 & $x$ & & \\
\hline Czechia & 0,51 & & & 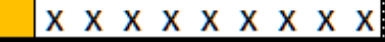 & $x \mathrm{x}$ & & \\
\hline France & 0,50 & & & \begin{tabular}{|l|lll} 
& $X$ & $X$ & $X$ \\
\end{tabular} & $x \times x \times$ & & \\
\hline Poland & 0,49 & & & $x$ & $x \quad x \quad x \quad x$ & & \\
\hline Greece & 0,49 & & & & $x \times x \quad x$ & & \\
\hline Slovakia & 0,49 & & & & $\begin{array}{llllllllllllll} & x & x & x\end{array}$ & & \\
\hline Hungary & $\overline{0,47}$ & & & & & $\mathrm{X} \times \mathrm{x} \times$ & \\
\hline Latria & 0,47 & & & & & $\begin{array}{lllllllllll} & x & x & x\end{array}$ & \\
\hline Slovenia & 0,47 & & & & & $x \quad x \quad x \quad x$ & \\
\hline Bulgaria & 0,46 & & & & & $\begin{array}{llll}x & x & x & x\end{array}$ & \\
\hline Italy & $\overline{0,43}$ & & & & & & $\mathrm{X} \times \mathrm{X}$ \\
\hline Romania & 0,43 & & & & & & $x \times x$ \\
\hline Portugal & 0,42 & & & & & & $x \times x$ \\
\hline
\end{tabular}

Figure 6. Classification of the European Union countries according to the modified synthetic measure of socio-economic development

Source: own compilation

In the next step, the EU member states are subjected to the hierarchical cluster analysis using Ward's minimum variance criterion. The modified synthetic measure of socioeconomic development is used again as the ranking variable. The results of Ward's cluster analysis are then compared with the method of delimiting objects (results presented in Figure 6).

In the second part there will be presented Ward's method which allow to classify the countries of European Union according to the modified synthetic measure of socio-economic development (see Figure 7). 


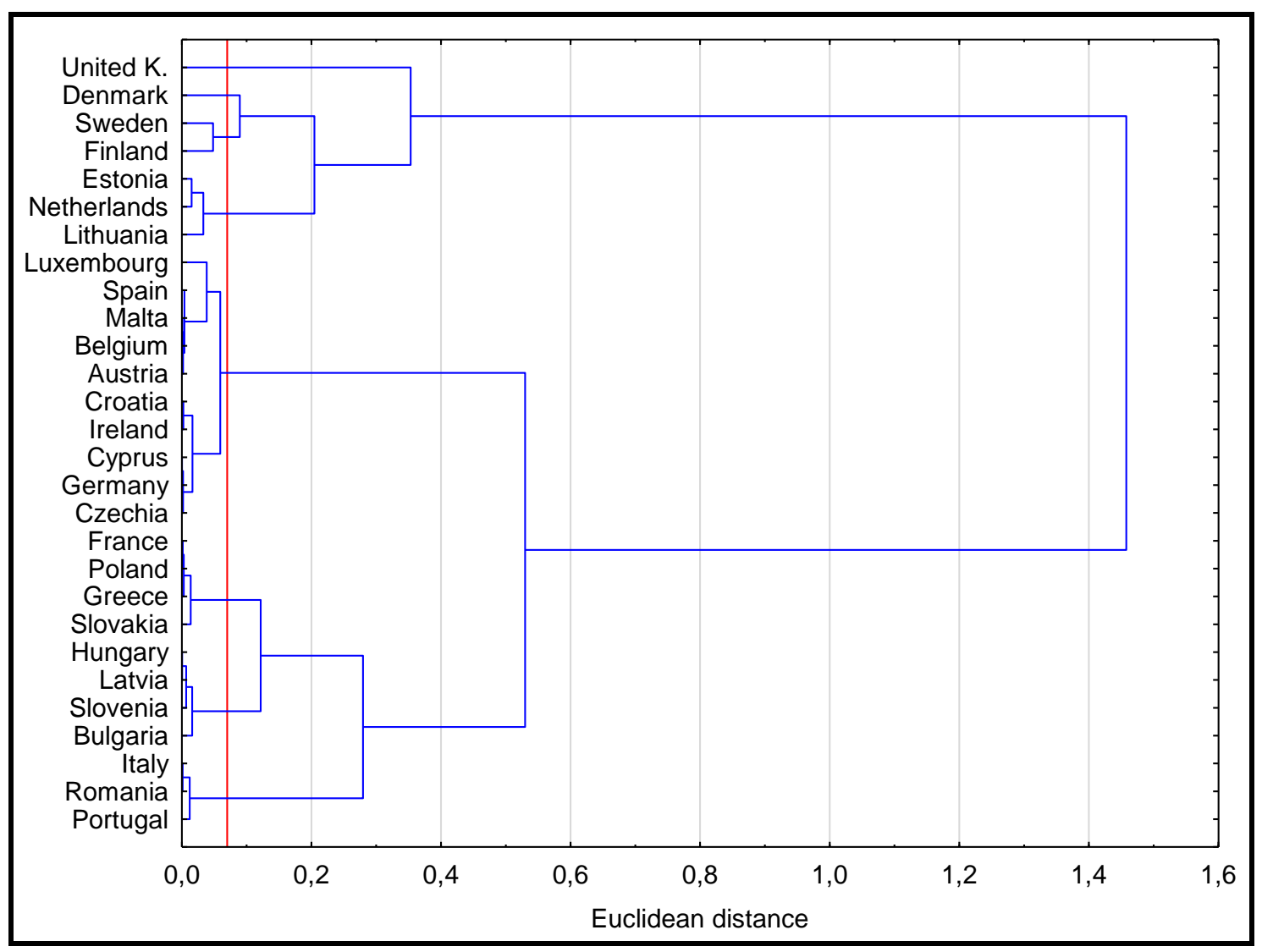

Figure 7. The classification of the European Union countries created using Ward's method for 8 groups

Source: own compilation

As you can see the results of delimitation are almost identical. The only difference concerns two countries: Sweden and Finland. In the Ward method, these countries are included in one group, and in the case of the vector delimitation method they are treated as two separate groups.

\section{Conclusion}

This paper presents a measure of the socio-economic development of the European Union residents that constitutes an alternative to the HDI - probably the most widespread metric of well-being. The synthetic measure presented herein is more nuanced relative to HDI as it is calculated with a richer set determinants that include variables related to the economy and finance, science and technology, health, education and living conditions. The analysis is supplemented with linear regression models intended to estimate the contribution of each determinant to the socio-economic development. Results reveal that the economy and finance determinant $(r=0.8)$, science and technology $(r=0.78)$ and living conditions $(r=0.84)$, have the greatest impact on socio-economic development, suggesting that these variables should routinely be include in the assessment of socio-economic development. 


\section{References}

Aguña, C. G., \& Kovacevic, M. (Ed.). (2010). Uncertainty and Sensitivity Analysis of the Human Development Index. Human Development Research Paper, 47/2010 [Report]. New York: Human Development Report Office.

Al-Hilani, H. (2012). HDI as a Measure of Human Development: A Better Index than the Income Approach? IOSR Journal of Business and Management, 2(5), 24-28.

Anand, S., Sen, A. K. (ed.). (1994). Human Development Index: Methodology and Measurement. Human Development Report Office Occasional Papers vol. 12. New York: Human Development Report Office.

Busato, F., \& Maccari, N. (2016). The Environmental Human Development Index, Rivista di Studi Sulla Sostenibilita', 14, 31-44.

Despotis, D. K. (2005). A reassessment of the human development index via data envelopment analysis, Journal of the Operational Research Society, 56, 969-980. DOI: 10.1057 /palgrave.jors.2601927.

Grabiński, T. (2017). Uproszczona metoda delimitacji wektorowej, Zeszyty Naukowe Uniwersytetu Ekonomicznego $w$ Krakowie, 5(965), 69-86. DOI: 10.15678/ZNUEK.2017.0965.0505

Grimm, M., Harttgen, K., Klasen, S., Misselhorn, M., Munzi, T., \& Smeeding, T. (2010). Inequality in Human Development: An Empirical Assessment of 32 Countries, Social Indicators Research, 97, 191-211. DOI 10.1007/s11205-009-9497-7.

Islam, S.M.N., \& Clarke, M. (2002). The Relationship between Economic Development and Social Welfare: A New Adjusted GDP Measure of Welfare, Social Indicators Research 57, 201-229. DOI:10.1023/A:1014481414637.

Jha, R.P., Bhattacharyya, K., Mishra, D., \& Pedgaonkar, S.P. (2017), Health Adjusted Human Development Index: A Modified Measure of Human Development, International Journal of Health Sciences and Research, 7(9), 207-220.

Kasprzyk, B. (2013). Wybrane aspekty oceny dobrobytu ekonomicznego i jakości życia (ujęcie regionalne - Podkarpacie), Rzeszów: Uniwersytet Rzeszowski.

Kovacevic, M. (2010). Review of HDI Critiques and Potential Improvements. Human Development Research Paper. 33/2010 [Report]. New York: Human Development Report Office.

Kubiczek, A. (2014). Jak mierzyć dziś rozwój społeczno-gospodarczy krajów? Nierówności Społeczne a Wrrost Gospodarczy, 38, 40-56.

Maccari, N. (2014, March). Environmental sustainability and Human Development: a greening of Human Development. Working Paper available at SSRN: http://dx.doi.org/10.2139/ssrn.2426073.

Migała-Warchoł, A. (2010), Ocena zróżnicowania poziomu życia mieszkańców województwa podkarpackiego, [in:] Borkowski, B. (ed.), Metody Ilościowe w Badaniach Ekonomicznych, XI/2, Warszawa: Wydawnictwo Szkoły Głównej Gospodarstwa Wiejskiego, 222-321.

Migała-Warchoł, A. (2017). Wykorzystanie metodologii wskaźnika HDI do badania poziomu życia mieszkańców krajów Unii Europejskiej. Humanities and Social Sciences, 24(3), 187-195.

Migała-Warchoł, A. (2018). The modeling of the socio-economic development in the European Union countries. Knowledge for market use 2018: Public finances in the background of sustainable development. International scientific conference proceedings. Olomouc: Palackỳ University, 309-315. 
Migała-Warchoł, A., \& Szczygieł, E. (2018). Classification of the European Union countries with an application of the modified Human Development Index, 5th International Multidisciplinary Scientific Conference on Social Sciences and Arts SGEM 2018. SGEM2018 Conference Proceedings, 5 (3.3), 87-94.

Mishra, S., \& Nathan, H.S.K. (2018). A MANUSH or HUMANS Characterisation of the Human Development Index, Journal of Human Development and Capabilities, 19(3), 398-415, DOI: 10.1080/19452829.2017.1422703.

Noorbakhsh, F. (1998). The Human Development Index: some technical issues and alternative indices. Journal of International Development, 10, 589-605.

Neumayer, E. (2001). The human development index and sustainability - a constructive proposal. Ecological Economics. 39, 101-114.

Petelewicz, M., \& Drabowicz, T. (2016). Jakość życia - globalnie i lokalnie. Pomiar $i$ wizualizacja, Łódź: Katedra Socjologii Ogólnej, Wydział Ekonomiczno-Socjologiczny, Uniwersytet Łódzki.

Pigou, A.C. (1932).The Economics of Welfare, London: MacMillan and Co.

Ranis, G., Stewart, F., Samman, E. (2006). Human Development: Beyond the Human Development Index. Journal of Human Development, 7(3), 323-358.

Sen, A. (1999). Assessing human development [in:] Human Development Report 1999, New York - Oxford: United Nations Development Programme and Oxford University Press.

Silva, R., \& Ferreira-Lopes, A. (2014). A Regional Development Index for Portugal. Social Indicators Research, 118(3), 1055-1085.

Stanton, E.A. (2007). The Human Development Index: A History, Working Papers wp127, Political Economy Research Institute, University of Massachusetts at Amherst.

Stiglitz, J., Sen, A., \& Fitoussi, J. P. (2009). Report by the commission on the measurement of economic performance and social progress.

ul Haq, M. (2003). The Birth of the Human Development Index. Readings in Human Development (S. Fukuda-Parr and A. K. Shiva Kuma ed., pp 127-137). Oxford, United Kingdom: Oxford University Press.

Woźniak M.G. (ed.). (2017). Gospodarka Polski 1990-2017. Kręte ścieżki rozwoju. Warszawa: PWN. 